\title{
The Importance of business ethics in business development
}

Tạp chí GTVT - The Importance of business ethics in business development

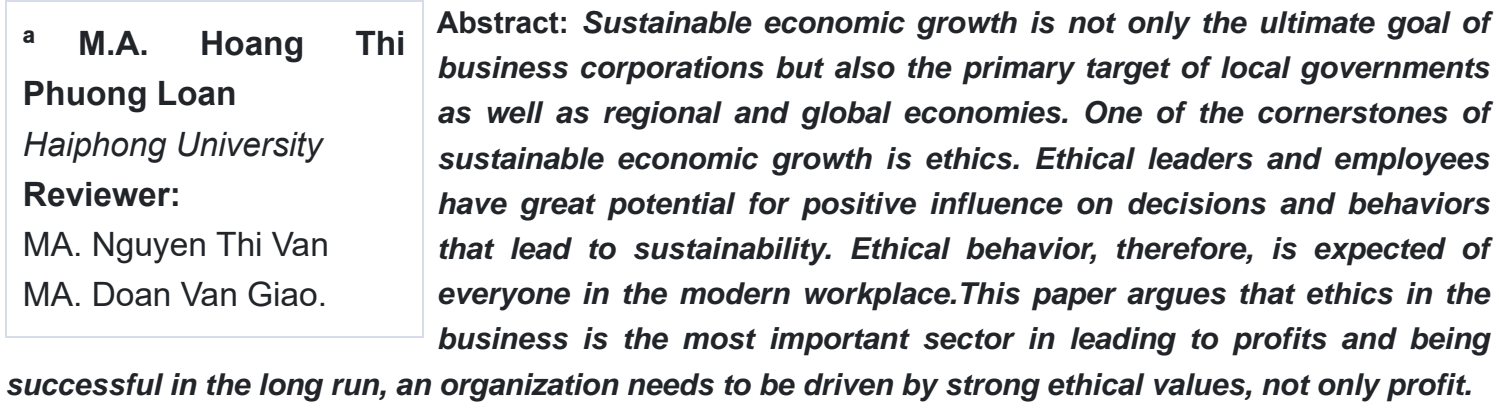

Keywords: Business ethics, profit, image of the company.

\section{Introduction}

Ethics is, at their essence, moral judgment about what is right and what is wrong. In a business sense, ethics is decided upon and formed by each company, employees must decide what they think is the right course of action because each individual's action within the company affects the entire company, not just the individual. When an employee acts ethically and responsibly, it helps the entire organization develop. Thus, business ethics is more than just words used to enhance the image of a corporation; it is the foundation for success and business ethics should be applied at the very moment a firm opens its doors.

However, the goal of maximizing profits is often in conflict with ethics because the main purpose of business is to maximize profits for its owners or its shareholders and only activities which increase profits are encouraged as this is the only way that companies will survive. Whereas, customers always have an interest in paying a low price for a good or service. Therefore, some questions are raised: "Should business people forsake ethics to achieve profit? Can they achieve profit with ethics in business? Why should business organizations be concerned with ethics?". This paper is an attempt to respond to these questions, with particular attention to business ethics .

\section{Development}

\subsection{What is business ethics?}

The term "business ethics" represents a combination of two very familiar words, namely "business" and "ethics". The word "business" is usually used to mean "any organization whose objective is to provide goods or services for profit" (Shaw and Barry, 1995). The word "ethics" refers to what humans ought to do, usually in terms of rights, obligations, benefits to society, fairness, or specific virtues. "Ethics" also means the continuous effort of studying our own moral beliefs and our moral conduct, striving to ensure that we, and the institutions we help to shape, live up to standards that are reasonable and solidly-based.

Business ethics considers the ethical relationship between businesses and consumers, between businesses and their employees. It also considers the impact of globalisation on the environment, and on society at large.

As Wikipedia, the free encyclopedia, says that "Business ethics is a form of applied ethics or professional ethics that examines ethical principles and moral or ethical problems that arise in a business environment. It applies to all aspects of business conduct and is relevant to the conduct of individuals and entire organizations".

According to Kirk O. Hanson, a renowned ethics expert who also doubles as the Executive Director of the 
Markkula Center for Applied Ethics, "business ethics is the study of the standards of business behavior which promote human welfare and the good."

As in Understanding Business Ethics, (Peter A. and Sarah D. Stanwick, 2008), it is said that "Business ethics is the study of business situations, activities, and decisions where issues of right and wrong are addressed". According to Garret, "Ethics is the science of judging specifically human ends and the relationship of means to those ends. In some way it is also the art of controlling means so that they will serve specifically human ends".

\subsection{The importance of business ethics in business develpment}

Business development is the creation of long-term value for an organization from customers, markets, and relationships. To develop business it is vital to take care of its business ethics.Debates and dilemmas surrounding business ethics have attracted a lot of attention from various quarters. Consumers and pressure groups have increasingly demanded that firms seek out more ethical and ecological ways of doing business. The media has also kept a constant spotlight on corporate abuses and malpractices. And even firms themselves appear to be increasingly recognizing that being ethical may actually be good for business. Ethical issues confront organizations whatever line of business they might be in. At the most basic level, business ethics is not just about the difference between right and wrong; it is the actual application of that knowledge to business.

Business has potential to provide a major contribution to the society in terms of producing the products and services, providing employment, paying taxes, and acting as an engine for economic development. However, how or indeed whether, this contribution is made raises significant ethical issues that go to the heart of the social role of business in contemporary society is a big question. The demands being placed on business that it should be ethical, by its various stakeholders, are constantly becoming more complex and more challenging. It is expected that business ethics can provide the means to appreciate and understand these challenges more clearly, in order that firms can meet these ethical expectations more effectively.

A business that behaves in an ethical way as a member of the community will often find that the community offers its support in return, which can also be invaluable to the success of the company. This may be done by assisting with community events, donating funds in support of local charities, or simply behaving honestly in dealings with other local businesses.

Business malpractices have the potential to inflict enormous harm on individuals, on communities and on the environment itself ultimately. By helping us to understand more about the causes and the consequences of these malpractices, business ethics seeks to improve the human condition.

It is clear that business ethics has not only been recognised as increasingly important, but has provided us with knowledge and skills which help us more understand the modern societies as its following 5 important roles.

\subsubsection{Business ethics attracts investment}

Business ethics attracts investors and keeps the company's share price high, thereby protecting the business from takeover. When a person or an entity is considering investment in a particular stock, there are a number of things they take into account. Aside from the quantitative factors surrounding a company's profit margin a future prospects, consideration is also given to a particular company from the point of view of the qualitative aspects such as their public image and the products that they happen to sell. All of these things are taken into account before the final investment is made.

Therefore, a company that would like to encourage extra business investment is a company that has a strong sense of business ethics. Part of business ethics is responsibility to the investor and for that reason companies with strong reputations in the field of ethical business behavior are also companies that tend to attract more investment from people that are new into the market. Investment is most definitely important to success.

Business ethics is also important in financial matters. This becomes clear when the business is dealing with people such as vendors and shareholders. A business that does not behave with integrity may have difficulty conducting business, as vendors who supply the materials it needs might not be willing to extend credit, while shareholders might no longer be willing to invest their money. While the initial profits might be high, the appearance of ethical problems within the business can make investors uncomfortable risking their money.

\subsubsection{Business ethics promotes benefits to the organization}


One of the main benefits for a business of behaving ethically is that a better image is given to the world at large, and especially to consumers, resulting in greater profit. It also means that expensive and potentially embarrassing public relation disasters are avoided. As far as employees are concerned, if the business is seen to behave ethically, for example with regard to the environment, it will recruit more highly qualified employees, and this leads to better employee motivation as the employees are proud of their jobs.

Working as an ethical business has many benefits, one of which is the ability to attract and keep investors, employees and customers. Knowing that the company they deal with has stated their morals and made a promise to work in an ethical and responsible manner allows investors peace of mind that their money is being used in a way that aligns with their own moral standing. When working for a company with strong business ethics, employees are comfortable in the knowledge that they are not by their own action allowing unethical practices to continue. Customers are at ease buying products or services from a company they know to source their materials and labour in an ethical and responsible way.

A positive and healthy corporate culture improves the morale among workers in the organization, which may increase productivity and employee retention; this, in turn, has financial benefits for the organization. Higher levels of productivity improve the efficiency in the company, while increasing employee retention reduces the cost of replacing employees.

\subsubsection{Business ethics adjusts employees' behavior}

Ethics in leadership within an organization can direct employees by example and guide them in making decisions that are not only beneficial to them as individuals, but also to the organization as a whole. When management is leading an organization in an ethical manner, employees follow in those footsteps and make better decisions in less time with business ethics as a guiding principle; this increases productivity and overall employee morale. When employees complete work in a way that is based on honesty and integrity, the whole organization benefits. Employees who work for a corporation that demands a high standard of business ethics in all facets of operations are more likely to perform their job duties at a higher level and are also more inclined to stay loyal to that organization.

Organizations that build positive business ethics into their corporate culture create a framework to keep the dialogue open and responsive to ethical considerations even as the business evolves and takes on new challenges. Knowing how to organically infuse ethics into everyday business practices and understanding how to communicate the importance of ethical behavior across divisions is a strong top-level leadership skill to develop.

\subsubsection{Business ethics improves public image of the company}

It is impossible to discuss business ethics as a branch of academia without taking a look at the relationship between business ethics and public image. Each corporation has a particular public image, which represents the way in which the public views the corporation. A corporation's environmental policy, the way they treat their employees and the way they treat the communities they exist in are all parts of their overall behavior and this in turn is the principle factor in determining their public image. As proof of this, you will notice that even though Wal-Mart makes products that have a decent quality and an extremely low price, they still have a negative public image.

Since public image is largely a result of company behavior, business ethics play a large role in determining public image since they determine behavior. And public image is one of the reasons as to why business ethics are important to a company's overall success.

A company which sets out to work within its own ethical guidelines is also less at risk of being fined for poor behaviour, and less likely to find themselves in breach of one of the multitude of laws concerning required behaviour - for example, laws around payments to corrupt regimes, or environmental practice policies. The whole company can be fined, the directors can be fined, and individual employees can be fined if the responsibility for an infraction falls on their shoulders.

Reputation is one of a company's most important assets, and one of the most difficult to rebuild should it be lost. Upholding the promises it has made is crucial to maintaining that reputation.

\subsubsection{Business ethics and socio - economic development}

In market economy, the enterprises produce and sell products and services in order to meet the demand of 
customers, get profit and continue their existence. While producing they make some flaws knowingly or without noticing. And this in turn leads to occuring of socio-economic problems in the society.

One of the most effective factors leading to socio-economic problems in society is the businessmen's breaching the ethical issues concerning the government. When we say the ethical issues concerning the government, of course we mean the delays in tax payment and not fulfilling the responsibilities towards the government bodies by the enterprises. Payment of taxes on time and in correct form will lead to sound formulation of country budget, prevent tax evasion and thus provide the socio-economic development of the country.

The ethical issues concerning suppliers and other agents (wholesellers, retailers, credit organizations, unions, etc.) have direct influence on the existence of the enterprises. If the agents showed above don't obey the ethical issues it leads to the destruction of the enterprises and as the result hundreds or even thousands of employees are unemployed.

The main issues in ethical issues concerning the internal environment of the enterprises are ethical issues concerning the shareholders of the enterprises. Thus, the managers of the organizations are appointed by the owners of the organizations. But some managers tend to earn undeserved income, don't obey the principle of loyality, and this takes the organizations into bankruptcy. As the consequence, it affects the society.

Finally, safety of employees and health of consumers should be mentioned. The establishment of a safe workplace is not only ethical but also social responsible of every enterprise. Products on the market must be ensured the safety of consumers. That would cause the reputation and long-term survival of the business.

\subsection{Principled approaches to business ethics}

A man needs a system of rational ethical principles to provide knowledge and guidance in real business situations. The purpose of business ethics is to discern the evaluative principles that are appropriate for the complex world of business. Explicit principles provide those engaged in business with a moral framework within which to think, evaluate, and act. Business ethics is concerned with how a businessman should act so that the goals of his company are attained in a manner consistent with applicable ethical principles. However, applying an ethical principle to complex concrete situations can be difficult and challenging.

Whereas, business in a free society requires honesty, prudence, integrity, justice, respect for contracts and property rights, and so on. Many business ethics issues revolve around the principle or virtue of honesty. An honest man attempts to gain values through productive action and voluntary exchange rather than by force or deception. Honesty as a principle is applicable in an authentic business context because it is necessary to allow men to live well on earth. Honesty means adhering to reality. An honest person does not gain at another's expense. Honesty means that it is wrong to gain value by faking reality or by misrepresenting the truth.

Managers define ethical business behavior in their workplaces by explaining to employees how behavior and action affects the business' overall mission. This approach helps employees understand the link between ethical business behavior and corporate success. In general, business ethical values are a set of guiding principles that encourage individuals in an organization to make decisions based on the company's stated beliefs and attitudes toward business practices within its industry such as:

-Conveying company alvues

-Creating an ethical workplace

-Fair treatment

-Acting with integrity

-Free market competition

-Safe products and services

•Enviromental protection

-Resolutely eliminate unethical behavior in business.

\section{Conclusion}

Setting a system of rational ethical principles in behavior and business is the foundation for business systems to reach sustainable development in general progress of humanity. Ethics is particularly important for the 
development and prosperity of a nation.

Businesses can increase sales or increase their reputation because of their ethical behavior. The goal of a business is not just to earn profit; to be successful in the long run, business organizations need to be ethical in dealing with customers, employees, investors, the community, and society.

In a sustainable business, employees at every level should be committed to the ethical standards of the business. And a business manager must be able to clearly define and communicate to the employees what factors and ethical standards expected to adhere to and what the consequences are for failing to meet those expectations.

The public now more and more expects the private sector to fulfill its ethical and environmental obligations because of its direct and serious impact on the public interest in modern society. Public opinion expects these enterprises to produce good results in all the balance sheets - financial success, ethics, social justice and sustainable development.

\section{Reference}

[1]. Cavico, Frank J. and Mujtaba, Bahaudin G. (2009), Business Ethics: The Moral Foundation of Effective Leadership, Management and Entrepreneurship (Second Edition), New York: Pearson Custom Publishing.

[2]. Kline, William (2006), Business Ethics From Internal Point of View, Journal of Business Ethics 64:57-67.

[3]. Shaikh Saleem (2010), Bussiness Environment, second edition, Dorling Kindersley, Peason Education.

[4]. Vương Quân Hoàng (2007), Văn minh làm giàu \& Nguồn gốc của cải, NXB. Chính trị Quốc gia (Sự thật).

f Chia sẻ Facebook

\section{BÌNH LUÂN}

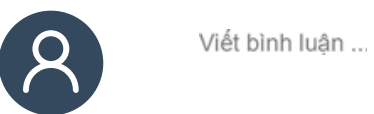

Dags: Business ethics profit image of the company

\section{TIN NÊN ĐOC}

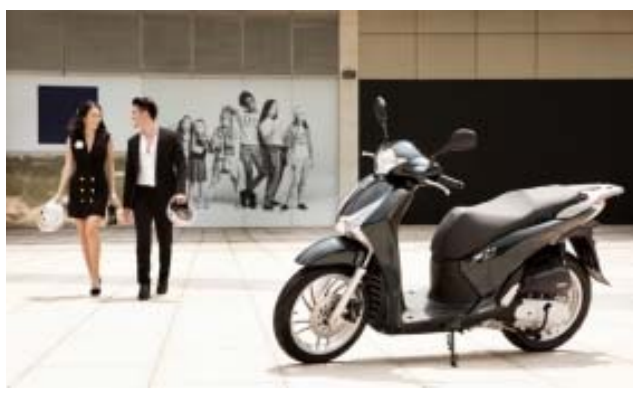

\section{Honda SH Việt "đột phá" vượt trội - kiêu hãnh} phong cách Châu Âu

02/05/2016 - 09:03

SH 125/150cc với những thay đổi hướng đến sự tiện nghi hơn cho khách hàng với hệ thống khóa thông minh Honda SMART-Key, được kỳ vọng sẽ là mẫu xe tiên phong. 


\section{References}

[1]. Cavico, Frank J. and Mujtaba, Bahaudin G. (2009), Business Ethics: The Moral Foundation of Effective Leadership, Management and Entrepreneurship (Second Edition), New York: Pearson Custom Publishing.

[2]. Kline, William (2006), Business Ethics From Internal Point of View, Journal of Business Ethics 64:57-67.

[3]. Shaikh Saleem (2010), Bussiness Environment, second edition, Dorling Kindersley, Peason Education.

[4]. Vương Quân Hoàng (2007), Văn minh làm giàu \& Nguồn gốc của cải. NXB Chính trị Quốc gia (Sự thật). 